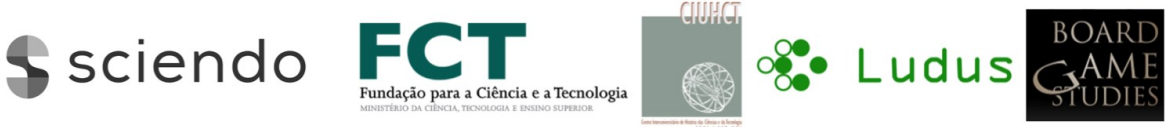

\section{Simulating SARATOGa: How SARATOGA- THEMED BOARD GAMES FUNCTION AS EXPERIENTIAL HISTORIOGRAPHY}

\author{
Maurice Suckling \\ Rensselaer Polytechnic Institute
}

\begin{abstract}
Games deeply informed by history are not merely games. They may not be detailed simulations, but, nevertheless, they are conscious or otherwise expressions of historiographical viewpoints. This paper examines the historiographical perspectives of nine board games, published between 1974 and 2019, all on one or more aspect of the Saratoga Campaign (1777).
\end{abstract}

\section{Introduction}

The Saratoga Campaign of 1777 has been much discussed by historians. The broad consensus is that the rebels won a victory over the British, Canadians, Loyalists, and their Native American allies with profound consequences for the development and outcome of the war. ${ }^{1}$ The surrender of Burgoyne's army at Saratoga (modern day Schuylerville), Upstate NY, October 17 was so significant that it persuaded Louis XVI the rebellion had sufficient momentum that the opportunity had arisen for France to redress recent reverses in the global balance of power. Following the French (March 1778), and later Spanish (April 1779), and Dutch declarations of war (December 1780, in response to a British preemptive declaration and offensives), and the Russian declaration of neutrality (March 1780), the strategic situation for Britain became deeply serious. The entire British global enterprise was threatened not just in North America, but also the

\footnotetext{
1 The thrust of Corbett's provocatively titled $\mathcal{N}_{0}$ Turning Point: the Saratoga Campaign in perspective is that the '...combined military and civil conflict continued for the rest of the war, and the British were consistently victorious, maintaining dominance of strategic Lakes Champlain and George. In the Hudson-Champlain valley...it is difficult to regard the Battles of Saratoga as a turning point.' Corbett, T. No Turning Point: The Saratoga Campaign in Perspective (Norman: University of Oklahoma Press, 2014), 5. The broad consensus of historians is that regardless of the local situation, the global one had most definitely altered.
} 
Caribbean, right through the Atlantic, Africa, the Mediterranean, The Indian Ocean, India, and into the Pacific. Not only that, but there were credible threats of invasion of Britain itself from France and Spain until the signing of the treaties in 1783/4 brought this now global war - or perhaps more accurately - interconnected cluster of global wars - to an end. ${ }^{2}$

Perhaps unsurprisingly the topic of the entire Saratoga campaign, and the climactic battles of Freeman's Farm (September 19) and Bemis Heights (October 7) have long engaged game designers too. Between 1974 and 2019 there have been ten published board games focused on some aspect of the campaign (one, or both of the key battles, or the overall campaign itself). This total excludes new editions of the same game (GMT's Saratoga, for example, was published 1998, 2006, 2014, and in 2017 as part of the Revolutionary War Tri-Pack), or even when the game shifted publisher, as Burgoyne vs. Gates (BvG) and Turning Point (TP) did. (In the latter case it did so with considerable modifications to the production, shifting from a DTP game when first published by BSO in 2001 - not 2005, as Board Game Geek has it at time of writing - to a full retail game when published by Worthington in 2009.) Nor does this list include the Freeman's Farm and Bemis Heights scenarios inside Decision Games' Rebels \& Redcoats Volume II (1995), PSC Games/Worthington Publishing's Hold The Line: The American Revolution (2016), or those same scenarios in Compass Games' Commands $\mathcal{E}^{2}$ Colors Tricorne: The American Revolution (2017). This list doesn't include selfpublished games such as Amold Takes Command: The Battle of Bemis Heights, or published tabletop rules for wargames with miniatures (or other pieces not supplied with the rule set). ${ }^{3}$ Nor does this list include the Saratoga campaign as it might be replicated as part of a published board game focused on the war (in North America) or a specific theatre of it (again, in North America) as a smaller part of a larger whole. ${ }^{4}$ In addition, there is my own Freeman's

2 Mackesy, P. The War for America 1775-1783 (London: Longmans, 1964), 190-200.

3 For Arnold Takes Command, see:

https://boardgamegeek.com/boardgame/244530/arnold-takes-command-battle-bemisheights (last accessed April 21, 2019). For tabletop rules see games such as Matt Fritz's Arnold's Finest Hour: http://www.juniorgeneral.org/awi/saratoga2.html (last accessed April 21, 2019).

4 Games such as 1776 (Avalon Hill, 1974), We The People (Avalon Hill, 1993), Washington's War (GMT, 2010), Liberty: The American Revolution 1775-83 (Columbia Games 2003), The American Revolution (Guild of Blades, 2006), 1775: Rebellion (Academy Games, 2013) Liberty or Death (GMT, 2016). This list of 'strategic level' games is far from exhaustive here. If there are other games specifically on Saratoga that I haven't detailed and don't meet those exclusions I would be grateful for information on them.

Board Game Studies Journal 14, pp. 83-108 DOI: $10.2478 /$ bgs-2020-0005 
Farm: 1777, which spun out of the analysis connected to this chapter, and was published by Worthington late 2019, but I have not examined that

\begin{tabular}{|l|l|l|l|l|}
\hline \multicolumn{1}{|c|}{ Year } & \multicolumn{1}{|c|}{ Name } & \multicolumn{1}{|c|}{ Publisher } & \multicolumn{1}{|c|}{ Playtime } & BGG rating \\
\hline $\begin{array}{l}1974 / 1 \\
976\end{array}$ & Burgoyne vs. Gates: Saratoga: 1777 & $\begin{array}{l}\text { Rand Game Associates/ Gamut } \\
\text { of Games }\end{array}$ & 90 mins & 5.5 \\
\hline 1976 & The Battle of Saratoga & Oldenburg Grenadiers & 180 mins & 7.5 \\
\hline 1982 & Birth of a Nation & 3W (World Wide Wargames) & 120 mins & 5.7 \\
\hline $\begin{array}{l}1998 / \\
2006 / \\
2014 / \\
2017\end{array}$ & Saratoga & GMT & 180 mins & $7.1-8.2$ \\
\hline $\begin{array}{l}2001 / \\
2009\end{array}$ & $\begin{array}{l}\text { Freeman's Farm September 19, } \\
\text { 1777 }\end{array}$ & BSO/Worthington Games & $\begin{array}{l}120 \text { mins/ } 90 \\
\text { mins }\end{array}$ & $6.3 / 6.2$ \\
\hline 2009 & Lion In A Net: Saratoga 1777 & White Dog Games & $?$ & 4.6 \\
\hline 2013 & Saratoga 1777 AD & Turning Point Games & 150 mins & 6.2 \\
\hline 2015 & First Saratoga: Burgoyne's Gambit & Decision Games & 90 mins & 5.2 \\
\hline 2017 & Saratoga 1777 & Worthington Publishing & $60-120$ mins & 7.7 \\
\hline 2019 & Campaigns of 1777 & Decision Games & 120 mins & 7.8 \\
\hline 2019 & Freeman's Farm: 1777 & Worthington Publishing & 60 mins & 8.4 \\
\hline
\end{tabular}

Table 1: Board games focused on some aspect of the Saratoga campaign, published 19742019. (BGG stands for Board Game Geek https://boardgamegeek.com)

particular game in this article.

From this list of ten games above only one (Lion in A Net) has so far eluded me, hence its omission in analysis. The intention behind this paper is to briefly explore the extent of historical simulation projected through these games. To be clear, these games never claim to be solely simulations, with the requisite level of historical accuracy that entails. Oldenburg Grenadiers' The Battle of Saratoga $\left(T B B_{S} S\right)$ does have front of box copy saying (in capitals): 'A MILITARY BATTLE GAME SIMULATION; AN HISTORICAL EDUCATION AID', and $B v G$ also describes itself as a 'simulation game', but for the most part, the games present themselves clearly as games - albeit closely inspired and deeply informed by historical events - and, as such, are 
primarily intended as entertainment. ${ }^{5}$ Indeed, Richard H. Berg's BSO publication of his TP makes a more modest claim in the rule book:

Turning Point is a game that allows players to recreate the main portion of the pivotal battle of the American Revolution: Saratoga. While we have made every effort to give the players as much history as possible, TP is a game. And while it may not be a history lesson, you, as players, can have a lot of fun trying to change the course of history. ${ }^{6}$

Perhaps $T B o S$ 's box copy and $B v G$ 's rules copy tell us as much about marketing trends and cultural contexts (perhaps how companies felt compelled to present their products to be sufficiently credible to be commercially appealing in the 1970s, and perhaps this had altered by the early 2000s) as it does about genuine claims to degrees of historical accuracy. Although the distinction between simulation and game is an important one to be aware of at a certain level of discussion, this isn't a distinction I explore here. In any event, regardless of the claims made on behalf of these titles, as suggested, and briefly explored, in a previous paper in The CEA Critic, my contention is that game design is a powerful means of effecting an historical viewpoint, whether conscious or not, and, further, that an examination of the design and - crucially- the experience of playing it - will reveal historical perspectives, which are, when so deeply informed by historical sources, worthy of some reflection. ${ }^{7}$ My goal then, is not to berate these games for being something they seldom make any claim to be - for failing at something seldom even attempted - namely persuasive historical assertions. Rather, it is to consider the validity these games may nevertheless have as expressions

${ }^{5}$ In the rules booklet the introductory text reads: 'The BATTLE OF SARATOGA (sic) game simulation has been designed to provide the game player with a maximum of historical content while also providing an entertaining format.' https://boardgamegeek.com/image/61774/battle-saratoga (last accessed April 21, 2019). Burgoyne vs. Gates: Saratoga: 1777, (Gamut of Games, 1976), 1.

6 Turning Point: The Battle of Freeman's Farm September 19, 1777 (BSO, 2001), 1.

7 The CEA Critic (Vol 79, Number 1 March 2017): 'Board with Meaning: reflections on the intersection between game design and historiography in the board games Twilight Struggle, The Lost Cause, and Quartermaster General: 1914.' https://muse.jhu.edu/article/652549/pdf 
of historical viewpoint beyond their own more modest claims - the ways they have succeeded in making detectable historical assertions alongside, or perhaps despite, more primary concerns such as being commercially viable entertainment experiences.

A note on the organization of this paper: I've broken the case studies into sections to aid the pacing of the discussion. There is one large section each on the 'campaign' level games, because they provoke many historiographical elements it takes some time to introduce and address in any detail. I have grouped all the 'tactical' level games into one section, and have concentrated solely on their distinct features as they pertain to the key historical debates they engender.

\section{Historical Overview}

The 1775 clashes in Lexington and Concord, and then Bunker Hill, left there no doubt that an insurrection was gaining momentum. In June the same year the Americans launched an invasion of Canada that floundered at the gates of Quebec as the year turned. Benedict Arnold did something to restore the strategic situation for the Americans by delaying the British counterattack down Lake Champlain sufficiently that the pivotal Fort Ticonderoga remained in American hands by the winter of 1776/7.

In New York and New Jersey Washington suffered a series of defeats at the hands of General Howe, the commander in chief of British forces in America. Only Washington's audacious victories at Trenton and Princeton helped salvage American morale and kept the rebellion's cause flickering.

In November 1776 General Howe wrote to the Secretary of State for the Colonies, Lord Germain, the minister tasked with essentially running the war, outlining a strategy for 1777 focusing on Albany as a target - to split the colonies and decapitate New England from the rest, to sever American lines of communication, and contain the contagion of rebellion in the north. ${ }^{8}$ In February 1777 Howe's thinking shifted to Philadelphia as his primary target. ${ }^{9}$ A few days later General Burgoyne, angling for command in America, presented his plans to Germain, which involved a three-army junction in Albany - Howe from New York, Burgoyne from Canada down the Hudson, and General St. Leger down the Mohawk valley.

${ }^{8}$ Nickerson, H. The Turning Point of the Revolution. (Port Washington, NY: Kennikat reprint 1928). 78.

${ }_{9}^{9}$ Black, J. War for America: The Fight for Independence, 1775-1783. (New York: St. Martin's Press, 1991).127

Board Game Studies Journal 14, pp. 83-108 DOI: $10.2478 /$ bgs-2020-0005 
Germain approved these plans, then received notification from Howe that he intended to approach Philadelphia via the Chesapeake, and in his May 18 reply clarified that Howe was to complete these operations in Philadelphia in time to cooperate with Burgoyne's army from Canada. Howe did not receive this until he had departed for Philadelphia via the Chesapeake, and, in any case, Germain had received Howe's revisions so late he may have had no real alternative but to simply approve them. ${ }^{10}$

As this letter attests, there was too much uncertainty as to how much collaboration was expected between Howe and Burgoyne, how much latitude they might have to devise that for themselves or to what extent they might operate independently as they saw fit - at least on Howe's part. One of the most highly contentious topics of the entire campaign - at least for the British - is who is responsible for the lack of coordination between Howe, Burgoyne, and Germain, and whether George III must also take some of the blame as he engaged in some oversight in these matters. There is even some suggestion that Howe's actions - especially his decision to move on Philadelphia via the Chesapeake - slower and less able to give support to Burgoyne in New York than had he moved via New Jersey or the Delaware Bay - was evidence of deliberate efforts to scupper Burgoyne's operations, preventing him from overshadowing Howe's own exploits in the war. ${ }^{11}$ However much that may be disputed, there is no doubt there were rivalries and there was discontentment throughout the British command structure. There was also, a sense for some, like Howe, that this was a war they shouldn't be fighting in the first place. ${ }^{12}$ No less significant, Germain was not a popular choice for Secretary of State. Further, operating along exterior lines of communication, as the Saratoga campaign did, with three armies seeking to intersect, clearly engenders difficulties - especially in an era reliant on the transference of written messages over vast distances - over 3,000 miles between Montreal and London. The realities of tides, winds, and contemporary maritime technology meant the Atlantic was roughly 'one month long' west to east, and roughly three times that east to west, adding to the possibility of confused orders. ${ }^{13}$ Moreover, the overland route

10 Ketchum, R. M. Saratoga: Turning Point of America's Revolutionary War (New York: Henry Holt. 1997). 79-84; 109; Mackesy, P. The War for America 1775-1783 (London: Longmans, 1964), 122.

${ }_{11}$ Adams, C. F. Campaign of 1777 (Proceedings of the Massachusetts Historical Society, Volume 44, 1910-11), 25-26.

12 Ketchum, R. M. Saratoga: Turning Point of America's Revolutionary War (New York: Henry Holt, 1997), 77.

13 Mackesy, 73. 
through the upper parts of Upstate NY, when not reliant on bodies of water, was not hospitable terrain for an eighteenth century army - heavily wooded, roads that were mere tracks, if not streams of mud, afflicted by long harsh winters and suffocating summers. ${ }^{14}$

Burgoyne's column reached the northern shores of Lake Champlain June 20, and by July 6 had retaken Ticonderoga. On July 16, Howe received news from Burgoyne buoyant prior to his Ticonderoga assault, and put to sea to initiate his Philadelphia campaign. At this point Burgoyne seems to have believed he was still heading to meet Howe. ${ }^{15}$ Howe instructed General Clinton, whom he left in command of New York, to effect some support for Burgoyne, but with only 7,000 men to control a large area Howe would have known how little that support might effectively count for. ${ }^{16}$ As has been noted, Howe's actions do make sense if he assumed Burgoyne would take time to capture Ticonderoga and intended to winter there. ${ }^{17}$ Indeed, Ticonderoga was a prize that fell faster to Burgoyne than either Howe or Washington would likely have anticipated.

After this initial alacrity, Burgoyne's column halted at Fort Edward to bring up supplies and was then slowed in advance by American actions felling trees, and dismantling bridges, and the effective use of light infantry tactics. This gave Gates the time he needed to consolidate forces at Saratoga and put his engineer, Kosciusko, to work at Bemis Heights. August brought significant American victories. First, at Bennington (August 16), when Burgoyne's vastly outnumbered detachment was utterly destroyed, constraining Burgoyne's options in terms of supply and flanking maneuvers. Then the ever-energetic Arnold defeated St. Leger at Fort Stanwix (August 22), ending the British pressure through the Mohawk valley.

Burgoyne's column finally approached Gates' assembling army in Stillwater. A bloody pyrrhic victory at Freeman's Farm (September 19) gave Burgoyne the field, but the casualties incurred crippled his army and the strategic initiative was effectively lost at this point - if, indeed, Burgoyne could ever be said to have had it. We might as easily say Howe was the only one who had ever really possessed it, and Burgoyne had only ever been laboring under an illusion of it.

14 These realities were not lost on the British prior to the campaign - take the testimonies of Charles Stuart, future conqueror of Menorca as a case in point. Mackesy, 123.

15 Ketchum, 231.

16 Corbett, 236.

17 The Wargamer, Number 18 Jan-Feb 1982, Hatton, P. 'Birth of a Nation, Historical Background', G.2 /20.

Board Game Studies Journal 14, pp. 83-108 DOI: $10.2478 /$ bgs-2020-0005 
The army's encampment began to take on a more permanent aspect, as redoubts began to form. Burgoyne waited for Howe and tried - with immense difficulty (and mostly failure) to send messengers through American lines to find out where Howe was. On September 20 a ciphered message from Clinton in New York reached Burgoyne through the American lines that Howe was in the Chesapeake '...with the greatest part of the army...' with Clinton clear he had too small a force '...to make any effectual diversion...' in Burgoyne's favor, but promising to '...try something...' 18 Burgoyne took this as encouragement to stay the course and to wait for Clinton's support to come to bear. So Burgoyne and Gates remained opposite each other for several weeks as, on each side, fortifications were developed. But while the Americans were getting stronger as militias began to congregate, Burgoyne's army was suffering from desertions and supplies were beginning to dry up.

With supplies running low and no sign of Clinton, Burgoyne attempted to probe rebel defenses. This foray quickly turned into a retreat and a fullscale rebel counterattack followed - the fight coming to be called the Battle of Bemis Heights (October 7), even though the British scarcely got any closer to them than they did at the battle of Freeman's Farm. After a tenacious defense of Breymann's Redoubt the rebels - again aided by the energies of Arnold - broke through and, as night fell, Burgoyne was forced to retreat. Now outnumbered around 3:1, and never able to outrun Gates, Burgoyne became surrounded at Saratoga, where he felt compelled to surrender the entirety of his remaining army. The consequences, in North America, and all around the world, would be dramatic. As Piers Mackesy has it: "The defeat at Saratoga is the clearest turning point of the war. It marked the beginning of a general war waged throughout the world..."19

\section{Campaign Level Games}

\section{Burgoyne vs. Gates: Saratoga: 1777 (Gamut of Games)}

This game is often listed as Saratoga: 1777 .

This is one of three published games, alongside Worthington's Saratoga 1777 (S1777), and Decision Games' Campaigns of 1777 (CO1777),

18 Snow, D. 1777: Tipping Point at Saratoga (New York: Oxford University Press, 2016), 149-150.

${ }^{19}$ Mackesy, 147. 
with a focus on the campaign as a whole - although the latter is rather more than that, as we shall see. Other games, such as GMT's Saratoga have a nominal 'campaign' scenario, that links the battles of Freeman's Farm and Bemis Heights together, so the consequences of the former have a localized impact on the latter. But I have interpreted 'campaign' in the sense more conventionally understood by wargamers. After all, whereas the scale of GMT's Saratoga's board covers just a few miles around Freeman's Farm and Bemis Heights, BvG covers a geographical range from St. John's, Canada, (Saint-Jean-sur-Richelieu) in the north, to Albany NY, in the south, and from Fort Oswego on Lake Ontario in the west to Pittsfield MA in the east. It's a roughly 250 square mile area adapted to fit onto the game board.

$B v G$ presents several historical realities, detailing the units present (their names, the types of units, and the timing, location, and likely circumstance of their appearance in the campaign), and representing some commanders attached directly to units. The army commanders themselves have no representational presence. The Burgoyne and Gates in this game are, in effect, the players themselves. In terms of social anthropology, this is topdown history - affairs are conducted by 'great men'. Indeed, the eyes of these 'great men' that players look through are so great that they can see all across the 250 square miles of the board, and have full visibility of all units on both sides at all locations at all times. Perhaps not so much 'great men' history as 'greatest'.

The game board shows a map of the area that represents logistical realities. It uses a point-to-point approach, linking key towns/forts along roads, lakes, or trails. This prevents movement to ahistorical (utterly impractical/impossible) regions within the spread of the map, and keeps the strategic channels of operation broadly locked to two of the campaign's historical axes: along the Hudson Valley (Lake Champlain/Hudson/Lake George), and along the Mohawk Valley (St. Lawrence/Lake Ontario) which connects to Albany via Fort Stanwix. The game simply does not permit movement directly through the heavily wooded lake area between the St. Lawrence and Albany. Armies must move along routes that armies could feasibly have moved. The game tells us that one move represents '...approximately three days of march or sail away'. ${ }^{20}$ Each turn a British unit may move one 'space', between one town/fort on the map and another - which usually represents around 10-20 miles to scale, but, especially down the St. Lawrence, which is traversed by boat, it's close to around 80 miles. We know that the British march rates varied. Sometimes 7 miles a day,

${ }^{20} B v G, 1$.

Board Game Studies Journal 14, pp. 83-108 DOI: $10.2478 /$ bgs-2020-0005 
sometimes 12 , but capable of more. ${ }^{21}$ But since the game defines no scale for its possible 50 turns the question of accuracy is rather moot. Perhaps each turn is 2 or 3 days to scale. Regardless, American units can always travel double the distance of British units, and only they can use the (potentially flanking) trails to the east of Lake George in an arc around Fort Edward, Skunk Creek, and Skenesboro. To offset this, somewhat, the British possess some light infantry that has a 2 in 3 chance of also marching an extra space each turn. The game, then, is telling us that the Americans are more mobile, and can evade the British; that the British deployment (and success) of light troops will be critical, and if the British have to withdraw they have no hope of outrunning the Americans, so a British offensive could rapidly transform into a disastrous retreat. In the optional movement rules, where there is a 2 in 3 chance each turn that most British units don't move at all, this is further exacerbated.

There is an optional movement rule for simultaneous orders, perhaps inspired by the culturally significant touchstone of the era, the game Diplomacy. This option has players writing down orders for every piece on paper, before revealing and executing those orders simultaneously. It's an eloquent (if practically somewhat cumbersome) expression of how these commanders couldn't always successfully predict the movement of their enemies. This could have real consequences as, especially to the east of the Hudson, outflanking maneuvers could unsettle expected patterns for the campaign.

The importance of supply is represented through the designation of specific towns/forts as supply points, and units must remain with a certain span of towns/forts in order to remain in supply. Once units come out of supply they have a three turn countdown to restore supply or be removed from the game.

In combat, it is invariably difficult to secure significantly favorable odds. This results in a general sense of attrition as forces tend to bleed away over several confrontations, rather than being obliterated in single encounters. Forts and entrenchments reduce a defender's casualties and slow down territorial progress for attacking units, even with a numerical advantage. In overcoming these defensive obstacles, the marshalling of limited artillery resources is critical.

The appearance of American militia units is related, in part, to the proximity of British forces to Bennington (for 'Vermont Militia'), and in part

${ }^{21}$ Morrissey, B. Saratoga 1777: Turning point of a revolution. (Oxford: Osprey Publishing, 2000), 42-43.

Board Game Studies Journal 14, pp. 83-108 DOI: 10.2478/bgs-2020-0005 
to random die rolls that bring NY Militia onto the board and remove them again. Overall this simulates the uncertainty of service duration that accompanied the militia units in the campaign. ('Vermont Militia' units are also doubled in combat value if they fight in Bennington but lose this modifier elsewhere.)

How might we interpret these various design elements and the experience of playing the game, from the perspective of an historical viewpoint? The most obvious and essential point to make is that there is no 'southern' dimension to the representation of this campaign. Albany is at the bottom of the game board, and there is no representation of any threat to it from British forces in New York. Nor is there any representation of a relationship between the movement of Howe's army and the Saratoga campaign. This either implies a determinist view - Howe was only ever going to do what Howe did, or expresses an opinion that the two campaigns are essentially better understood, and explored, as discrete and separate operations. Although perhaps few military historians (myself included) would support this latter interpretation, we might bear in mind that Howe's own actions (if not his broader thinking) at the time demonstrate a viewpoint evidently in line with the designers.

Without this Albany to New York City axis, the game is telling us even without Howe, or Clinton, Burgoyne could still have won the campaign. Yet it is also telling us what a dicey proposition this was. Only assembling data on accumulated playthroughs will reveal details of the game balance beyond the anecdotal, but, for the designers, arguably the more finely balanced it is the better it might be as a game. ${ }^{22}$ Frequently historians feel that without any hope of significant forces from New York Burgoyne's chances of success were rather less than finely balanced, and veered dramatically closer to the desperately thin, or perhaps even worse. ${ }^{23}$ The anticipated levels of Loyalist support did not materialize, the Rebels were more numerous than expected, and the terrain was too unforgiving for large, fully operational, supply lines. If Burgoyne had known there was never any hope of significant forces coming from New York with which to 'effect a junction' - the whole initial thrust of his entire campaign - then he

22 Despite its general sense of game balance, and other elements to recommend it, perhaps it has fared relatively poorly in its review score on Board Game Geek because combat execution is rather fiddly. The constant mathematics of one third fractions feels overly cumbersome, particularly for more modern players accustomed to more elegant and less convoluted systems.

${ }^{23}$ O'Shaughnessy, A. The Men Who Lost America: British Command During the Revolutionary War and the Preservation of the Empire. (London: Oneworld Publications, 2014), 150-160. 
perhaps would not have embarked on his drive south to Albany in the first place and the whole scheme would never have been approved by Germain in London. But, then again, Burgoyne seems to have drunk rather too much of his own Kool-Aid and certainly underestimated the Americans in numerous ways. His decision not to withdraw after Freeman's Farm might be desperation from Clinton's cipher fueled by his own sense of pride - and continuing underestimation of his enemy. After leaving New York City garrisoned, Clinton only had around 3,000 men at his disposal. Howe, in contrast had around 15,000.24

The design also tells us that right at the beginning of the campaign Burgoyne had more options than he might have considered. He might have increased the ratio of forces he allocated to St. Leger's flanking attack. He might even have made this his main attack column. Indeed, this was the route General Carleton advocated. It was the route General Amherst had taken in 1760 - south to north - and Mackesy tells us Clinton, amongst others, considered it the easier way. ${ }^{25}$ Burgoyne also might have settled for a lesser victory, and even relatively late on, he might have settled for securing Ticonderoga and Fort George (and, more importantly, avoided the defeat that so excited the French). So, in these regards, the game projects a view about the campaign which we might here describe as non-determinist, that even without any possibility of support from Howe, it was still a feasible enterprise with a reasonable chance of success. This may not be a popular view amongst historians, but, as stated earlier, the point of this paper isn't to discredit overly speculative history, but to detect historical viewpoints carried inside the design.

Various design elements combine to deliver a sense in which, for the British player, the decision on how to split forces down the Hudson or Mohawk valleys is utterly critical, and shapes much of how the rest of the campaign unfolds. Because American forces continue to be frequently augmented through most of the first 25 turns, the British are compelled to act as fast as they can, to achieve the most favorable odds in combat, securing the most advantageous locations on the board before the odds swing decidedly away from them. The faster and farther south they move the more tension there is on British supply lines, so the more decisions there

24 There is rather more to it than this. From Burgoyne's letters he evidently felt compelled to push towards the intended junction with Howe and St.Leger in Albany to comply with orders, even when it was apparent Howe would not be there, and the realities of the strategic situation were starting to bite. Snow, 16.

25 Mackesy, 114 
are to make about how many forces to leave behind to protect flanks and to secure supply lines, or how many to keep with the main columns. As the odds begin to favor the Americans the British will need to decide whether to try to push on towards Albany in an attempt to secure a 'strategic victory', or to cut their losses and to try to settle for the lesser 'tactical' or 'minor' victories' that a more defensive stance makes likely. Of course, the less aggressive the British player is the less pressure is on the American player and the more options they have to push for their own ultimate victory secured by eliminating high numbers of British units and securing Albany and Fort George.

For the American player the key decision is how to react to initial British moves. The rapid arrival of British troops around Fort Stanwix needs a response, drawing troops away from what could be the main threat coming down the Hudson. Do American units attempt to hold on to Fort Ticonderoga, or Fort George, or Fort Edward? Or do they pull back south to Saratoga, ceding ground and strategic position for more numerous concentrated forces? Can they use the trails around Skenesboro to threaten the supply line at Ticonderoga? (As my research assistant found to his peril, no, they cannot if they have lost their artillery - at which point most of the potential pressure from flanking moves on British supply lines evaporates.)

The design is grounded in its approach to movement, combat, and supply, which are all regulated by seemingly reasonable degrees of probability. The game encourages us to ask level-headed counterfactuals like, what if Burgoyne had caught the American troops at Mount Independence around Ticonderoga (June 27)? Those troops would have taken no further part in the campaign, and could that have had an impact on the eventual outcome? What if Burgoyne had made the Mohawk Valley his main attack route? Could Burgoyne have operated on the east bank of the Hudson in a more adventurous way? How much difference could a British success at Fort Stanwix have made? Ultimately, I suggest $B v G$ is telling us the campaign was more finely balanced than many historians may agree, but is a blend of broadly determinist and non-determinist diachronic perspectives. $^{26}$

Saratoga 1777 (Worthington Publishing)

26 The game moves less in favor of the British with the optional movement rule, and with the base combat rules which don't use the dice roll activated result matrices.

Board Game Studies Journal 14, pp. 83-108 DOI: $10.2478 /$ bgs-2020-0005 
The Mike and Grant Wylie designed $S 1777$ covers a slightly smaller area than $B v G$ - around 200 square miles - but it shares a number of similarities. It too gives us point-to-point movement, albeit at a smaller scale. It gives us a board that represents the Hudson and Mohawk valley axes and gives no real Howe/Philadelphia dimension to the campaign (this isn't entirely the case, but I will return to this). Movement is slow for the British and most American units move faster. Again, the British player is compelled to move as rapidly as possible early on while they have numerical superiority - but must balance this with the risk of attacking in too fragmented a fashion. As with $B v G$, the American player must also dance around British thrusts until reinforcements arrive and the strategic situation moves in their favor. So, overall, the whole rhythm of the game is somewhat similar to $B v G$, and indeed, to the campaign itself as historians have generally recounted it.

There are, however, also distinct differences. The most obvious to declare is the use of a block game design. This design first became popular in the 1970s, but has enjoyed a renaissance since then, epitomized by the continuation of Columbia Games and the expansion of its range, and also by the publications of Worthington on a variety of topics. Units are represented by blocks, which have details printed on the side facing the player who controls them. This elegant analogue solution models the fog of war concept, with opposing players aware of where enemy units are, but not their details without the need for charts, screens, or a referee (or digital systems) to manage outputs. In addition to this, there is an Activation Point (AP) system that regulates how many units each player can move - which is especially punishing for the British player. This models the difficulty in getting units to do what you want. It is possible to conserve some AP for use later on more ambitious moves, which neatly models preparation for surges in the campaign. In addition, players roll to acquire AP which can dictate who goes first each turn, which plays its own havoc with player intentions. A simple implementation of a forced march concept further unsettles the 'greatest man' perspective of the design. Players risk losing strength points if they push their units faster than they are accustomed to moving. All told, there are real limitations for the players. They may still be able to see the whole campaign at all times, which units are where, but they will infrequently know with any certainty what the strength of those enemy units is, and there is a considerable loss of agency when it comes to moving their own units. A sort of 'great-ish, partially sighted, partially constrained man' type of history. 
Combat is more destructive - armies can be obliterated far quicker than in $B v G$, if the players decide to slug it out - potentially in a single turn, and supply is modelled in a far simpler way. Out of supply units don't expire after a duration, but they instantly become more difficult to move. The scale of the game - just 20 turns - is far shorter than $B v G$, such that any substantial delay to British forces will most likely condemn them to defeat without necessarily bringing the Americans to a major battle. In effect, a large portion of the British forces being out of supply is tantamount to defeat, regardless of whether these units expire or not.

The Howe/Philadelphia dynamic is modelled, in a limited sense. The British commander Clinton has the capacity to syphon off some American forces. But utilizing Clinton in this way costs AP, representing the idea that Burgoyne expends effort in communicating and/or galvanizing Clinton. The essence of this design is Burgoyne is essentially on his own, but an effective coordination with Clinton could have a significant bearing if either Burgoyne or St. Leger are sufficiently advanced towards Albany to be able to take advantage of it.

Also worthy of comment is the British player has significantly less latitude to shift the focus of the attack from the Hudson valley to the Mohawk. The main attack will always be down the Hudson. We might say this element is more determinist than $B v G$.

That said, the towns featured on the board permit an exploration of more counterfactuals around the nature of the campaign east of the Hudson. Might Burgoyne have applied more pressure here? Indeed, the victory conditions for the British - securing Fort Ticonderoga and Albany, or Ticonderoga, Manchester, and Bennington gives the British player more latitude than Burgoyne historically felt he had (or was eager to communicate that he felt he had), and appears to model the idea that Burgoyne might have adapted his plan and settled for a lesser victory of putting substantial pressure on Albany going into the winter of 1777/8. A Ticonderoga/Manchester/Bennington victory would not be the rebellionending decapitation of New England that Burgoyne had envisaged, but it would be the severing of some vital ligaments around Albany. It would also, crucially, not be a France-enticing defeat.

\section{Campaigns of 1777 (Decision Games)}

In support of many historians, including myself, Harold Buchanan's design Campaigns of 1777, manifestly links the Saratoga and Philadelphia 
campaigns together. ${ }^{27}$ There is no Burgoyne at Saratoga - at least not in the form we have come to know - without Howe at Philadelphia. Everything that happened in the northern colonies was deeply interlinked. The victory conditions - for the British to hold Montreal, Fort Ticonderoga, Albany, Fort Montgomery, New York City - and, to have at some point, captured Philadelphia - all within ten turns - demonstrates how this interconnectedness is a finely balanced puzzle. The British, desperate for the war to end quickly, must try to achieve these objectives across a map roughly 450 miles by 350 by the end of the campaign season of 1777 . The Americans, desperate to hold on, must play a wrecking game, disrupting and spoiling British initiatives.

As with $B v G$ and $S 1777$, point-to-point movement focuses movement and combat along historically viable axes, and supply is modeled too. As with $S 1777$ the judicious deployment of individual leaders and their abilities is crucial. As with $B v G$, all units are visible at all times by both players. The leader ability values ('rank', 'leadership', 'range', 'attack', and 'defense') are all visible to both players at any time. As with $B v G$ this omniscient point of view is hardly a unique design feature, for obvious reasons. Board games have not inconsiderable issues with representing the fog of war if they are also to be playable (often in solo play) and commercially practical. Hence the enduring appeal of block games. Nevertheless, the historiographical implication is again 'greatest man'-leaning; commanders can see far more about the shape of a campaign than would be reasonable to assume they historically could. CO1777 certainly tells us Burgoyne and Howe's actions are deeply interrelated. But it also tells us each one can clearly know where the other one is at any point. However, CO1777 does make a practical and somewhat successful attempt to address this. The roughly two-week scale of each turn means that even broad knowledge of dispositions doesn't necessarily feel historically strained -units can't travel quickly across the board anyway so independent commands are often, in effect, being modeled in the system. More significantly, though, the turn order is essentially random, as dictated by a chit pull system. This does something to represent the difficulty of coordinating attacks across commands and theatres of operation. So even if Burgoyne and Howe can 'see each other' on the board at all times, they can't be sure who will 'activate' in what order, or, indeed,

27 The design is already sufficient evidence of this, but Harold has further expressed this view in correspondence. I should also point out, however, that CO1777 also offers optional scenarios to play the Saratoga/Philadelphia campaigns in isolation, as means of learning rule concepts.

Board Game Studies Journal 14, pp. 83-108 DOI: 10.2478/bgs-2020-0005 
if American units will activate before them, so the positional information, accompanied by entirely visible information on strength point totals and commanders abilities are only useful up to a point. Unfavorable turn orders can wreck plans and generate new, perhaps unexpected opportunities for both sides. This 'non-greatest man' perspective is compounded by commanders having the potential to intercept attacks and retreat from battle out of usual turn sequence.

Also of note, the 'Sea Travel Track', which allows Howe to disappear from the board, and to reappear at a place known in advance by the British player, but the American player is left to wonder where he will make landfall. This is a neat encapsulation of the British strategic trade off: powerful surprise at the expense of time and the effective removal of those forces from the war for that duration, and the associated American uncertainty at where to expect the hammer to fall.

In addition, the random event rolls help to generate a further fog of uncertainty for players, and is an effective simple means of generating a form of historically informed interactive fiction - as die rolls walk us through a sequence that sees Arnold appointed to a command in Albany; the engineer Kosciuszko's arrival; Schyluer's replacement by Gates; Gates and Arnold fight. Or, for the British Brant and the Indian troops leave the campaign; Carleton refuses to garrison Ticonderoga; Jane McCrea is murdered; Clinton is released from New York City. There is much more to be said about these random events than I have room for here, but they are blend of determinist and non-determinist history. Here things may tend to happen, but they do not necessarily happen. If they do, they will occur in a sequence. These random events also have the potential (with a double 6 on 2 dice - a $2.78 \%$ chance) to further destabilize expected movements and the 'greatest man' type of history board games are often prone to, by gifting players additional activations - with the potentially huge consequences this could entail. Of additional note, in the British random event table, are events that could delay sea movement or cause casualties - which further seems to suggest removing Howe from the campaign to effect sea movement is risky.

Two final comments on the game: the 'rally' mechanic instills a dynamism into the campaign - with numbers and locations of troops altering in line with probabilities that make historical sense, but that are not entirely predictable. The optional 'Expert Leaders' feature is a kind of RPG-lite 'levelling up' or 'skilling up' mechanic that means leaders change and grow over the course of the game. This again speaks to a kind of dynamism, but 
without historical determinism. This change is predicated on success. If a leader does well at something (storming a fortress, or intercepting, for example) they have an improved chance of doing better at it next time. Commanders do not begin with these attributes, they must earn them over the course of the game.

\section{Tactical Level Games}

\section{Saratoga (GMT)}

GMT's Saratoga covers an area of just a few miles and allows players to combine the battles of Freeman's Farm with Bemis Heights. The design highlights several discussion points, upon which the campaign might have turned. In a similar fashion to $\$ 1777$, player turn order is not regulated, but can be inverted by rolling lower for 'initiative'. This has the impact of disrupting the simple flow of plan to execution, leaving a movement that would be unproblematic, or at least potentially calculable, with a set turn order, to be open to flanking attacks or other counter-maneuvers. It is a means of expressing a limited degree of command control, that speaks to Clausewitz's concept of 'friction' ("In war everything is simple, but the simple things are difficult.") beyond the dice rolls of combat or movement rates, showing how unpredictability can run so deep that conducting a battle can be as much reaction as action. ${ }^{28}$

Ammunition use is logged in the combined Freeman's Farm/Bemis Heights 'campaign', allowing for players to explore the consequences of American ammunition being depleted and see if the British could exploit this. The advent of fog is simulated, which complicates the British advance and gives the Americans more time to not only disrupt the British left flank with Arnold's division, but also could minimize the negative impact of Gates' relative stasis. In particular the potency of Morgan's and Dearborn's units and their effectiveness in disrupting the British advance is highlighted. The game allows us to model the consequences if the British can isolate these units, destroy them, or otherwise neutralize them.

Saratoga also emphasizes the significance of the presence of leaders to influence combat and the morale of nearby units. The design encourages

28 http://clausewitz.com/readings/OnWar1873/BK1ch07.html (last accessed April 21, 2019). 
the careful placement of leaders at key junctures in the battle(s). The game also tracks an army's overall morale, which has a bearing on the turn defining initiative roll mentioned above (essentially, the more units are destroyed the more an army's morale falls) and influences individual unit morale checks. This design element clearly projects the depletion of an army's morale as a critical element and tempers the sense of agency commanders can feel in command situations.

\section{Saratoga $1777 A D$ (Turning Point Games)}

Saratoga 1777 AD (perhaps somewhat confusingly by a publisher called Turning Point Games) also uses a similar initiative concept, albeit in an even more simplified form. The effect is the same: the potential turn sequence can be disrupted, so a player can go last in one turn, and first in the next, giving them two 'turns' back to back. The placement of leaders also matters and gives some combat bonus. But most worthy of note is the commander's 'activation' rating (Burgoyne: 3, Arnold: 2, Gates: 1). Commanders have a limit to the number of subordinates they can 'activate', who must also be in range of them. Their subordinates, in turn, can activate all units they command that are also close enough to them, and they then move these units at full values and bring them into offensive contact with the enemy. In this way, the design emphasizes the importance of cohesive formation control and coordination, which is predicated on commanders being in the right place at the right time.

\section{First Saratoga: Burgoyne’s Gambit (Decision Games)}

Burgoyne's Gambit ( $B$ 's $G$ ), tells us a British assault on Bemis Heights had a reasonable chance of success, and that the British occupation of Gates' HQ or Bemis Tavern, or substantial pressure on the American left (having units in, or being the most recent to pass through, specific hexes) would equate to a victory. Fog is lightly modelled, modifying movement, but, in essence, all units and all unit capabilities are visible at all times. The tight micromanaged control of units moving incrementally in full sight of the enemy, working with understood odds and probabilities, is the means of achieving victory. 
Birth of a Nation (3W)

Birth of a Nation is as much a tactical/company level miniatures game redolent of its era with cardboard units on a hex grid as much as a tactical/company level board game on the topic of Freeman's Farm. As commanders, players control all their units and micromanage them into position, navigating terrain, enemy zones of control, enemy fire (while not 'phasing'), shifts in formation (column/line, and limbered/unlimbered), bridge repairs, firing, assaults (melee), and morale tests. It tells us units were compelled to operate within close proximity of their respective commanders or suffer significant tactical disadvantages. The victory conditions compel the British to try to take Bemis Heights, and the disposition of the victory condition hexes encourage the seizing of Freeman's Farm and the American left. The rules restricting the American player's agency, especially at the start of the game, also reflect the piecemeal commitment of American forces into the battle.

\section{Turning Point (BSO/Worthington)}

Turning Point sees Richard H. Berg return to the Freeman's Farm subject for a second time, having been the designer behind Birth of a Nation nearly twenty years earlier (as well as a dizzying number of other wargames over the length of his prolific career). It's a significant shift away from that earlier design. It's a dice-less system, reliant on card play within a squared grid of a board depicting the historical topography with system modifiers (units move slower in woods, for example, and bestow defenders advantages in melee). The constrained hand from a random draw inside tailored decks for each side in the card play does something to simulate the operational difficulties for commanders - as they try to coordinate between units to compose and maintain coherent battleplans. The system allows for the possibility of units becoming stranded and outflanked as the commander's limited hand prevents him from enacting better options. With the tabled reinforcements, and full visibility of all units on the board at any time it tells us that even with full visibility of the battlefield commanders cobble together plans out of opportunities the enemy presents, as much as through those he crafts for himself.

The game balancing ensures that both sides must move fast, and control of Freeman's Farm can be critical to control the battle's momentum. The balancing also seems to be telling us that the majority of units on either side 
may have little real involvement in the battle, which may, ultimately, be decided by relatively few units in key positions. A viewpoint that is certainly in line with the historical consensus but is perhaps problematic in terms of a player experience. ${ }^{29}$

\section{Conclusion}

Games designed so deeply inspired by history are manifestations of historical viewpoints, regardless of their claim to historical accuracy or any claim to simulation. Each design element is an articulation of more than merely a design element, it is a way of 'doing' history, an expression of values held.

$B v G$ is a form of top-down history, with all-but unconstrained visibility and agency, with a mix of determinist elements (the lack of Howe being key, together with the American force' movement bonuses) and non-determinist (such as the optional rule on hidden movement).

S1777 is a top-down history with considerable constraints in agency and limitations of various other kinds (including intelligence), with its own different blend of determinist elements (the lack of Howe, the Hudson valley route focus), and non-determinist elements (such as with the broader victory conditions).

CO1777 is also top-down demonstrating limitations in timing that can compel players to rework plans in a localized context -i.e. just within the range of a senior commander. The set leader abilities, regulated movement rates and victory conditions might be deemed determinist. Whereas the chit pull mechanic for initiative, and the 'Expert Leader' option, in particular, destabilize that perspective.

All three of these 'campaign' level games have victory conditions that make the British player feel the necessity of speed yet punish recklessness. They all demonstrate to the American player what happens if you neglect maneuver and attempt direct confrontation with the British too soon. The British player's starting positions and units make them feel powerful in each case, but the task in hand- especially within the allotted time of $S 1777$ and

${ }^{29}$ Perhaps this, combined with the rather fiddly nature of the constant facing rotation to try to incur flank attack bonuses, accounts for the relatively poor reception to this system, especially in comparison with near namesake Richard Borg's largely card-driven system seen in Battlecy and the Command $E^{2}$ Colors series with which TP shares some similarities. Anecdotally, Mike Wylie of Worthington informs me the system in TP, first seen in Richard H. Berg's Waterloo, derives from a bet that he could design a dice-less system. 
CO1777 - feels daunting and the number of units feels barely sufficient at best. The American player feels undermanned, and assailed on all sides, hoping time might generate the reinforcements they need to stem the red tide.

The tactical level games also compel the British player to act fast or run out of time to satisfy victory conditions, yet also punish recklessness. So, the British player is on the horns of a dilemma that is experientially freighted. Act too slow and lose, act too fast and lose. All of these games put the onus on the British player to dictate the specific shape of the battle and the areas of particular focus. (Although the objective locations on the game boards already telegraphs where those conflict zones are likely to be.) The American player waits and tries to accurately predict British movements and attempts to run down the clock to frustrate the satisfaction of those victory conditions.

In all these games there are unsupportable historiographical projections - most often connected to the extent of visibility and micromanaged control of units. Of course, there are wholly understandable design convention reasons for these projections. But my real point here is that regardless of those issues, in all these games, on either side, players can feel what historians are telling us about the battles - most especially about Freeman's Farm. The British player must move and chance their arm and commit to make headway. The American player must choose the right place to hold their ground. Some of these games also find some way of representing the cautious Gates and preemptive Arnold dynamic, which somewhat complicates the specifics of the American player's options.

What next? I shall continue to try to hunt down a copy of Lion In $A$ Net. The Rebels \& Redcoats, Hold The Line, and Commands \& Colors Tricorne scenarios are also games I intend to play and consider as time permits. Sometimes, particularly with the tactical level games, even if there are - as I argue - historical viewpoints intrinsically wrapped up inside the design, they are not necessarily strikingly original and worthy of particular comment. But until I play these games I couldn't comment for sure. I am familiar with the systems - at least in the case of Hold The Line, and Command E Colors and my expectation is that the extent to which the design abstracts history to work within these systems will be more revealing about implied historiographical perspectives rather than less.

I briefly mentioned earlier my own Worthington published design, Freeman's Farm: 1777. But a discussion on what that game has to tell us historiographically, through virtue of its design - would seem to be better 
left to another time. In any case, it may be better conducted through voices other than my own. Just because a designer has clear intentions they wish to convey it doesn't necessarily follow that they have conveyed them or that they are the best judge of what has actually been conveyed to players. After all, I am maintaining here that it is what players feel that might critically engage us most - or at least far more than it hitherto has done - as we consider the physiological and psychological ramifications of game design, and what a potent medium it is - not just for introductory level education, and entertainment, but also for artistic, philosophical, and historiographical expression.

\section{References}

\section{Primary Sources}

Burgoyne vs. Gates: Saratoga: 1777, Rand Game Associates/ Gamut of Games (1974, 1976).

The Battle of Saratoga, Oldenburg Grenadiers (1976).

Birth of a Nation, 3W (World Wide Wargames) (1982).

Saratoga, GMT (1998/2006/2014/2017).

Turning Point: The Battle of Freeman's Farm September 19, 1777, BSO/Worthington Games (2001/2009).

Saratoga 1777 AD, Turning Point Games (2013).

First Saratoga: Burgoyne's Gambit, Decision Games (2015).

Saratoga 1777, Worthington Publishing (2017).

The Campaigns of 1777, Decision Games (2019). 


\section{Secondary Sources}

[Adams, 1920] Adams, C. F. Campaign of 1777. Proceedings of the Massachusetts Historical Society, Volume 44, 1910-11.

[Allison and Ferreiro, 2018] Allison, D.K. \& Ferreiro, L.D. (Eds) The American Revolution A World War. Washington, DG: Smithsonian Books, 2018.

[Bender, 2019] Bender, T. Strategy \& Tactics, (316, May-June 2019): '1777: Year of Decision'.

[Bird, 1963] Bird, H. March to Saratoga: General Burgoyne and the American Campaign, 1777. Oxford: Oxford University Press, 1963.

[Black, 1991] Black, J. War for America: The Fight for Independence, 1775-1783. New York: St. Martin's Press, 1991.

[Corbet, 2014] Corbett, T. No Turning Point: The Saratoga Campaign in Perspective. Norman: University of Oklahoma Press, 2014.

[Ferling, 2007] Ferling, J. Almost a Miracle: the American Victory in the War of Independence. Oxford: Oxford University Press, 2007.

[Glickstein, 2014] Glickstein, D. After Yorktown: The Final Struggle for American Independence. Yardley: Westholme, 2014. eBook.

[Higginbotham, 1983] Higginbotham, D. The War of American Independence. Northeastern University Press, 1983.

[Ketchum. 1997] Ketchum, R. M. Saratoga: Turning Point of America's Revolutionary War. New York: Henry Holt, 1997.

[Logusz, 2010] Logusz, M. O. With Musket \& Tomahawk: The Saratoga Campaign and the Wilderness War of 1777. Haverton PA: Casemate, 2010. 
[O'Shaughnessy, 2014] O'Shaughnessy, A. The Men Who Lost America: British Command During the Revolutionary War and the Preservation of the Empire. London: Oneworld Publications, 2014.

[Mackesy, 1964] Mackesy, P. The War for America 1775-1783. London: Longmans, 1964.

[Morrissey, 2000] Morrissey, B. Saratoga 1777: Turning point of a revolution. Oxford: Osprey Publishing, 2000.

[Nickerson, 1967] Nickerson, H. The Turning Point of the Revolution. Port Washington, NY: Kennikat, 1967.

[Pancake, 1977] Pancake, J. S . 1777: The Year of the Hangman. University, Alabama: University of Alabama Press, 1977.

[Russiello, 1972] Russiello, W.R., Albert, L.J., and Nofi, A.A. (1972) The Saratoga Campaign, 1777. Strategy \& Tactics, (30), 18-28.

[Snow, 2006] Snow, D. 1777: Tipping Point at Saratoga. New York: Oxford University Press, 2016.

[Suckling, 2017] Suckling. M. The CEA Critic (Vol 79, Number 1 March 2017): 'Board with Meaning: reflections on the intersection between game design and historiography in the board games Twilight Struggle, The Lost Cause, and Quartermaster General: 1914.'

The Wargamer, Number 18 Jan-Feb 1982, Hatton, P. 'Birth of a Nation, Historical Background'.

\section{Internet Sources}

https://www.academia.edu/10108456/Logistics_Failure_of_General_Bur goyne 
https://www.armyupress.army.mil/Portals/7/educational-services/staffrides/Staff-Ride-Handbook-Saratoga-Campaign.pdf

https://babel.hathitrust.org/cgi/pt?id=njp.32101015131541;view=1 up;se $\mathrm{q}=13$

http://clausewitz.com/readings/OnWar1873/BK1ch07.html 